\title{
Science in a crisis: conducting clinical trials in an emergency
}

\author{
P Horby
}

From 3rd International Clinical Trials Methodology Conference

Glasgow, UK. 16-17 November 2015

In the closing plenary lecture, Prof Peter Horby describes the challenges of conducting clinical trials in emergency settings.

Published: 16 November 2015

doi:10.1186/1745-6215-16-S2-13

Cite this article as: Horby: Science in a crisis: conducting clinical trials in an emergency. Trials 2015 16(Suppl 2):13.

Submit your next manuscript to BioMed Central and take full advantage of:

- Convenient online submission

- Thorough peer review

- No space constraints or color figure charges

- Immediate publication on acceptance

- Inclusion in PubMed, CAS, Scopus and Google Scholar

- Research which is freely available for redistribution

Submit your manuscript at www.biomedcentral.com/submit

\section{() Biomed Central}

